\title{
THE MINERALOGICAL CHARACTERISTICS AND THE ZONING OF THE HYDROTHERMAL TYPES ALTERATION FROM NISTRU ORE DEPOSIT, BAIA MARE METALLOGENETIC DISTRICT
}

\author{
FLOAREA DAMIAN ${ }^{1}$
}

\begin{abstract}
The hydrothermal alteration types, which have affected intrusive and volcanic rocks from Nistru ore deposit, are related to fluids composition varied in their evolution within hydrothermal systems. The early stage of the hydrothermal activity has produced extensive propylitisation and potassic alteration (orthoclase, biotite, sericite) associated with the central part of the quartz-micromonzodioritic porphyry stock. The late stage of the fluids differentiation is determined by the hydrogen-ion metasomatism (phyllic alteration, argillic alteration), characterized by a large vertical variation. The hydrogen-ion metasomatism is associated with the bor metasomatism, generated by acid solutions and at a high temperature. The vertical and lateral zoning character of the hydrothermal alterations is related to differences in rock composition and variation in physical-chemical conditions during the periods of subvolcanic intrusion and mineralization.
\end{abstract}

Keywords: Alkaline metasomatism, Hydrogen-ion metasomatism, Bor - metasomatism, Zoning.

\section{INTRODUCTION}

Nistru ore deposit is situated in the NW part of the Oaş-Gutîi Neogene volcanic chain. The mineralogical composition of the Nistru ore deposit includes native gold, chalcopyrite, galena, sphalerite and a complex series of bismuth sulfosalts (Damian, $1999 \mathrm{~b}$ ). The ore minerals are concentrated in the veins commonly localized in volcanic rocks and subordinately on the contact zone of the subvolcanic bodies with the volcanic rocks or within subvolcanic bodies.

Măldărescu \& Măldărescu (1965) classified the hydrothermal alteration phenomena within the types and facies specific for the effusive formations from the Baia Mare zone.

The geological and metallogenetical studies for Nistru ore deposit were made by Borcoş et al. (1972). According to these studies, the metallogenetical activity is controlled by the Piatra Handal volcanic structure and the vein groups are emplaced on the north-western and south-eastern flank of the Piatra Handal structure.

Stanciu (1972) described hydrothermalised areas located in the southwestern part of the Neogene volcanic massif. The hydrothermal alterations are associated with pyroxene andesites (Sarmatian age) and quartz andesites (Pannonian age). The areal distribution and the spatial zonality around the base-metal and gold-silver mineralizations of the hydrothermalized zones were described

\footnotetext{
${ }^{1}$ North University of Baia Mare, 4800 Baia Mare, Dr. Victor Babeş Street, No. 62/A
} 
as following: the propylitized zone, the chlorite zone, the adularia zone, the sericite zone and the argillitic zone.

\section{GEOLOGICAL SETTING}

The geology and the evolution of the volcanic and metallogenetic activity in the western part of the Gutîi Mts were described by Rădulescu (1958), Cioflica (1956), Giuşcă (1960) and Borcoş et al. (1972). The products of the volcanic activity are represented by rhyolites, dacites, pyroxene andesites and quartz andesites (Badenian, Sarmatian, Pannonian age). After Borcoş et al. (1972), the intrusive activity took place after the eruption phase of the pyroxene andesites and the subvolcanic bodies are represented by sarmatian pyroxene andesites (for Aluniş, Țapu, Piatra Handal volcanic structures) and by pliocene pyroxene andesites as domes (for llba and Săbişa).

The research in the deep levels of the Nistru ore deposit have led to the emphasizing of a suite of magmatic rocks consolidated at subvolcanic level, placed at approximately $200 \mathrm{~m}$ deeper than the present surface. The suite of magmatic rocks consolidated at a subvolcanic level follow in succession the phase of Sarmatian pyroxene andesites (Fig.1). They are spatially associated to the volcanic rocks, being distinguished by morphological and structural aspects as well as by petrographic types. They are porphyritic and equigranular and appear as stocks, apophyses, dykes or sills, Damian (2000).

The petrographic types separated in the two veins fields (NW and NE$\mathrm{SE})$ are related to two magmatic chambers with distinct evolution, Damian (1999 a). The subvolcanic rocks from the NW part of the Nistru ore deposit are represented by porphyry phase of quartz-microdiorites with lateral transitions to andesitic facies. The NE-SE vein field is related to porphyry quartz-micromonzodiorites stock, accompanied by their apophyses, which outcrop on the Nistru Valley (Fig. 1). The types of hydrothermal alteration were separated by the minerals assemblages formed through reaction of the wall rocks heat solutions with different chemical composition. The zoning of the type hydrothermal alteration, mineralogical composition and spatial position within the ore body has permitted their integration in specific patterns of the hydrothermal system.

\section{THE MINERALOGICAL CHARACTERISTICS OF THE TYPES HYDRO-} THERMAL ALTERATION

The alteration and mineralization in the Nistru area were controlled by subvolcanic intrusions located in the central part of the vein fields. The hydrothermal alteration types have been separated based on those described by Meyer \& Hemley (1976) and Rose \& Burt (1979).

\section{Propylitic alteration}

Propylitic alteration is typical for the mineralogical assemblage: albite, chlorite, epidote, carbonates, sericite, pyrite, magnetite. Propylitic alteration in the inner zone of the hydrothermal ore deposit has pervasive character. The 


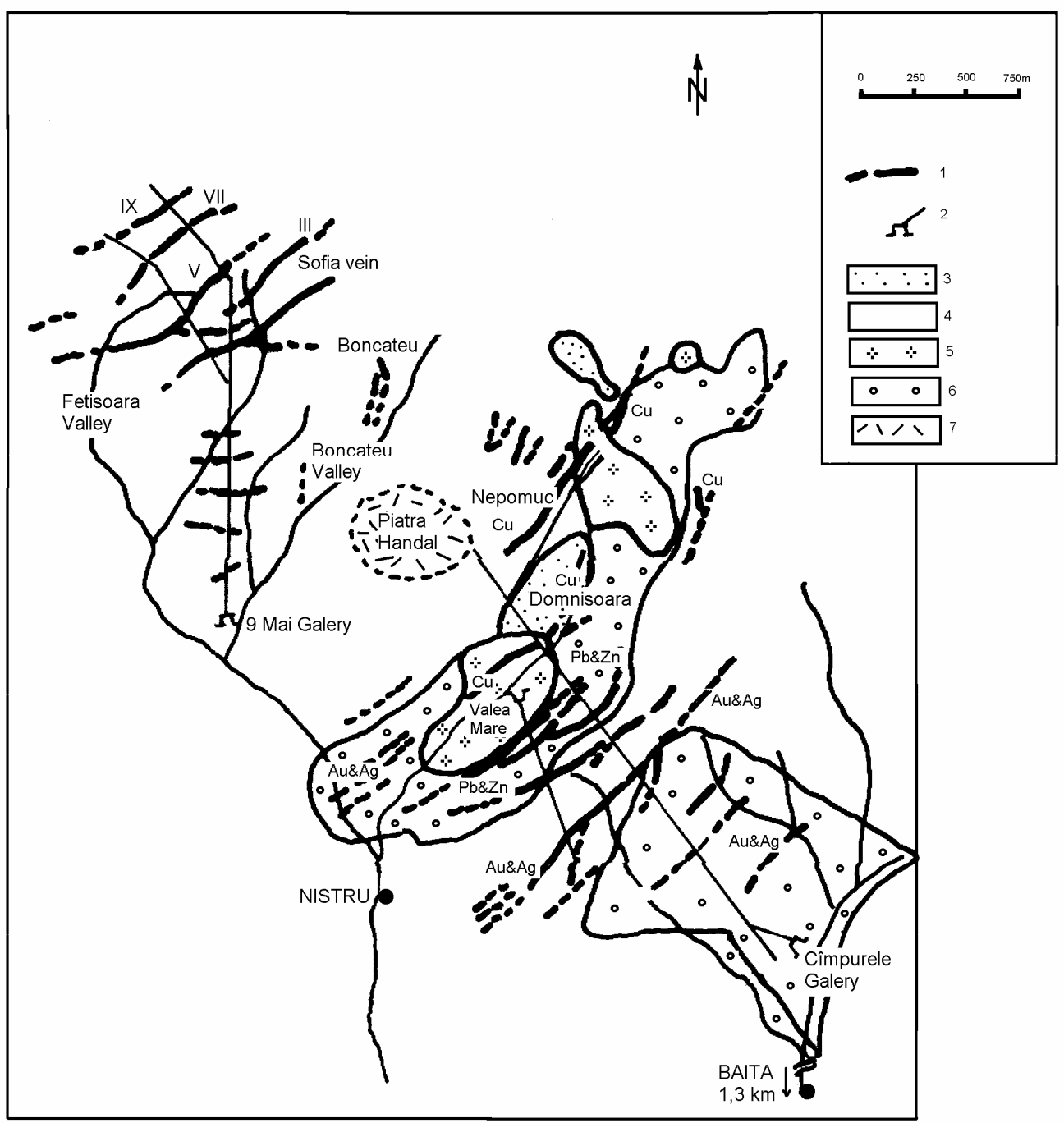

Fig. 1. Spatial distribution of the ore deposits in the Nistru area. 1. Vein system, 2. Gallery, 3. Quaternary, 4. Pyroxene andesites (Sarmatian age), 5. Quartz-monzodiorite, 6. Pyroclastic rocks (Badenian age), 7 Volcanic neck (modified after Borcoş et al. 1972). 
plagioclases crystals are replaced by aggregate of sericite, chlorite, epidote and calcite (Plate I, Fig. 1). The pyroxene crystals are substituted by carbonates and quartz. Outward vein fields into unaltered rocks, plagioclase feldspars are unaltered or are incipiently altered along the plane of macle by aggregate of epidote and calcite associated with bands of albite (Plate I, Fig. 2). Within the propylitic alteration there have been separated the actinote zone (inner propylitization) (Plate II, Fig. 1), situated in the central part of the porphyry quartzmicromonzodioritic stock and the propylitic epidote-chlorite zone, which is situated in the marginal part of the stock.

The presence of the chlorite as a dominant mineralogical phase within the propylitic alteration has determinated the separation of the chlorite zone to the vein mineralizations rich in copper in the NW part and subordinately to the copper vein group in the NE part of the Nistru ore deposit. Propylitic alteration is developed extensive in the inner part and around the subvolcanic bodies. In the pyroxene andesites the propylitic alteration appears on large areas in the exterior parts of the veins or as relict zones between the veins. The propylitic alteration is usually disposed in the exterior parts of the alteration types from near the veins. The propylitic alteration affects the deeper parts of the subvolcanic rocks and it is associated with the pyrite-copper \pm molybdenite and scheelite assemblage from the NW part of the Nistru ore deposit.

\section{Potassic alteration}

The characteristic minerals of the potassic alteration are K-feldspar, biotite and sericite. This mineralogical assemblage develops with a pervasive character in the central part of the porphyry quartz-micromonzodiorite stock. The potassic alteration with adularia is specific for the epithermal system associated with volcanic rocks. The potassic alteration, characterized by the replacement of the primary minerals with secondary biotite, K-feldspar, sericite is associated with sulphides (pyrite, chalcopyrite) and magnetite. This mineral assemblage suggests the presence of a "porphyry copper" system. The potassic feldspar substitutes the plagioclase. The biotite, as lamellar or as grain crystals substitutes the plagioclase phenocrysts and the mafic minerals (Plate II, Fig. 2). Together with the sericite, apatite and quartz they also form grain aggregate in groundmass (Plate III, Fig. 1). The quartz, associated with calcite and pyrite, forms veinlets in the core zone of the stock. Gradually, in the exterior part of the potassic zone follows the phyllic and propylitic alteration.

Potassic alteration with adularia is characterized by the replacement of the plagioclase feldspars by the triclinic adularia, associated with sericite (Plate III, Fig. 2). The adularia is also accompanied by varying quantities of other minerals such as chlorite, sericite, quartz, pyrite as substitutes for the mafic minerals or as aggregates in groundmass of the volcanic rocks. The potassic alteration with adularia is associated with gold-silver veins and partially, with the upper part of the $\mathrm{Pb}-\mathrm{Zn}$ veins. 


\section{Phyllic alteration}

Phyllic alteration is typical for the assemblage quartz-sericite-pyrite. The phyllic alteration is characterized by the complete substitution of the plagioclase feldspars by sericite (Plate IV, Fig. 1) and of the mafic minerals by quartz. The porphyry structure of the rock is still visible, the primary components of the groundmass are pervasive substituted by the sericite-quartz-pyrite assemblage. The association of the tourmaline with the mineralogical assemblage of the phyllic alteration is a characteristic of the porphyry quartz-micromonzodioritic stock (Plate IV, Fig. 2).

The tourmaline appears as radiare aggregate or as prismatic crystals in the quartz and sericite aggregate. The phyllic alteration appears in the exterior part of the potassic alteration from the central part of the quartz-micromonzodioritic stock. It is typical for the adjacent zones of the veins within the main intrusions. The distribution and mineralogy of the phyllic assemblage are the result of the successive periods of fluids circulation in the fractured rocks. The phyllic alteration is associated with the base-metal veins and partially with the copper veins from the volcanic area.

\section{Argillic alteration}

Argillic alteration is characterized by the formation of the clay minerals by extreme base leaching of alumino-silicates. The argillic alteration is associated with the upper parts of the vein fields and affects the volcanic rocks. The argillic alteration is characteristic for the gold-silver veins from the SE part of the Nistru area. The association of the argillic alteration with secondary silica is specific for the copper veins from the NE-SE field.

The clay minerals, which substitute the plagioclases and mafic minerals, are represented by illite, kaolinite and montmorillonite. In the rocks intensely affected by the argillic alteration, the clay minerals replace completely the components of the rock.

\section{Silicification}

This type of alteration is frequently present as a distinct type associated with base-metal veins. The silicification is also associated with argillic and phyllic alteration. Within the subvolcanic bodies the silicification has partially affected the near zone of the copper veins. The silicification affects the pyroxene andesites from the southern part of the NW area. The quartz substitutes the mafic minerals and it is frequent associated with chlorite and carbonates.

\section{THE ZONING ALTERATION}

The zoning alteration from Nistru area is determined by the variation of the composition in the magmatic intrusions, by the variation of the physicochemical conditions in the mineralization periods specific to the two magmatic chambers (NW and NE-SE). In the NE part of the area, associated with the porphyry quartz-micromonzodioritic stock, the horizontal zoning of the alterations 
is clear. This zoning is associated with the zoning of the specific mineralizations. In the central part of the stock, the potassic alteration (K-feldspar+biotite), associated with disseminations of pyrite and chalcopyrite, is emphasized for a porphyry-copper system. The central vein zone contains copper veins with bismuth sulfosalts at a high temperature. The phyllic alteration is disposed in the exterior part of the potassic zone. This is associated with base-metal veins and partially with the copper veins situated in the nearest parts of the quartzmicromonzodioritic stock. Within the phyllic alteration, specific to the quartzmicromonzodioritic stock, the hydrogen-ion metasomatism is associated with the bor metasomatism. In the outward parts of the quartz-micromonzodioritic stock there are disposed argillic alteration, silicification and potassic alteration (adularia). These are associated with gold veins and with the upper part of the base-metal veins.

The zoning of the alteration associated with the porphyry quartz-microdiorite body from the NW part of the Nistru area is typically vertical. In the deepest parts of the intrusions the propylitic alteration is predominant and it is associated with the copper level of the veins. The phyllic alteration is present, with an extensive development in the quartz-microdiorite body and especially in the lava flows of the pyroxene andesites, associated with the $\mathrm{Pb}-\mathrm{Zn}$ levels of the veins. The upper parts of the volcanic structure are dominated by the argillic alteration together with the silicification specific to the complex character levels ( $\mathrm{Pb}-\mathrm{Zn}-\mathrm{Cu} \pm \mathrm{Au}-\mathrm{Ag})$ of the veins. The overlapping is specific for the alteration types in the Nistru ore deposit. The overlapping of the metasomatic effects reflects the successive afflux of the fluids generated by multiple magmatic events.

\section{CONCLUSIONS}

The vein fields from the Nistru ore deposit, developed in volcanic rocks in relation to subvolcanic intrusions, has represented the favourable conditions for the convective circulation of the meteoric fluids, which have penetrated the permeable zones at deep levels. Through their cooling, the subvolcanic intrusions have generated, in an early stage, heat and fluid phases, which have produced their metasomatism. In a later stage of the magma crystallization, the fluids have been exsolved and by condensation, they formed the hydrothermal solutions. The fluids with a low salinity have ascendant moved through the fractures system in the central parts of the subvolcanic intrusions and in the rocks from around these. In the early stage of the evolution the fluids produce autometasomatism of the rocks. The first stage of the metasomatism is alkaline metasomatic represented by the propylitic and potassic alteration (K-feldspar, biotite assemblage). The next stage in the fluids' evolution is dominated by the hydrogen-ion metasomatism characterized by a wide range of effects, from removal of $\mathrm{Ca}$ and $\mathrm{Na}$ to complete leaching of $\mathrm{Na}$ and $\mathrm{Ca}$. In this way the phyllic and argillic alteration are emphasized. The hydrogen-ion metasomatism is associated with the bor metasomatism, caused by the overlapping over the products of the previous stage of acid solutions of a relative high temperature. 


\section{REFERENCES}

Borcoş, M., Gheorghiță, I., Lang, B., Stan, N., Volanschi, E., Mîndroiu V. 1972, Considerații privind activitatea metalogenetică asociată andezitelor piroxenice sarmațiene din S.W. munților Gutîi (Ilba- Nistru- Băița), Stud. Teh. Seria I, nr.6, p. 65-91, Bucureşti.

Borcoş, M., Lang, B., Peltz, S., Stan, N. 1972, Evoluția vulcanismului neogen în partea de vest a munților Gutîi (Negreşti-Seini-Băița), Stud. Teh. Seria I, nr. 6, p. 7-37, Bucureşti.

Cioflica, G. 1956, Studiul geologic şi petrografic al formațiunilor eruptive din regiunea Băița (Baia Mare), Anal. Univ. C.I. Parhon, Ser.Şt. Nat., vol. 11, Bucureşti.

Damian, F. 1999 a, Studiul Mineralogic, Geochimic şi Genetic al Mineralizațiilor de Sulfuri din Regiunea Nistru - Baia Mare, Universitatea Bucureşti, teză de doctorat, 117 p.

Damian, F. 1999 b, Bismuth minerals-Native gold association in the copper mineralisation from Nistru - Baia Mare zone, Studia Universitatis Babeş-Bolyai, Geologia XLIV, 1, p. 151-158, Cluj-Napoca.

Damian, F. 2000, The evolution of the magmatic and metallogenetic processes in the Nistru area (Gutîi Mountains), Mineralia Slovaca, 32, p. 263-264, Bratislava.

Giuşcă, D. 1960, Adularizarea vulcanitelor din regiunea Baia Mare, Stud. cerc. geol., geogr., Ser. Geol.V, 3, p. 274-280, Bucureşti.

Măldărăscu, I. Măldărăscu Maria 1965, Asupra unor probleme privind alterările hidrotermale din regiunea Baia Mare, Anal. Univ. Ser. geol. geogr. Anul XIV, 1, p. 27-39, Bucureşti.

Meyer, C., Hemley, J.J. 1967, Wall rock alteration, in Geochemistry of hydrothermal ore deposits, Barnes H.L., ed., Holt, Rinehart and Winstone, p. 166-232, New York.

Rădulescu, D. 1958, Studiul petrografic al formațiunilor eruptive din regiunea Seini-llbaNistru (Baia Mare), Anuarul Comit. Geol., vol. XXXI, p. 151-294, Bucureşti.

Rose, A. W., Burt, D. M. 1979, Hydrothermal alteration, in Geochemistry of Hydrothermal Ore Deposits, Barnes H.L., ed. Second Edition. John Wiley and Sons, p. 173-235, New York.

Stanciu, C. 1972, Procese de transformare hidrotermală asociate mineralizațiilor dintre Racşa şi Dealul Crucii (Munții Gutiii), Stud. Teh. Seria I, nr.6, p. 37- 63, Bucureşti. 


\section{PLATE}

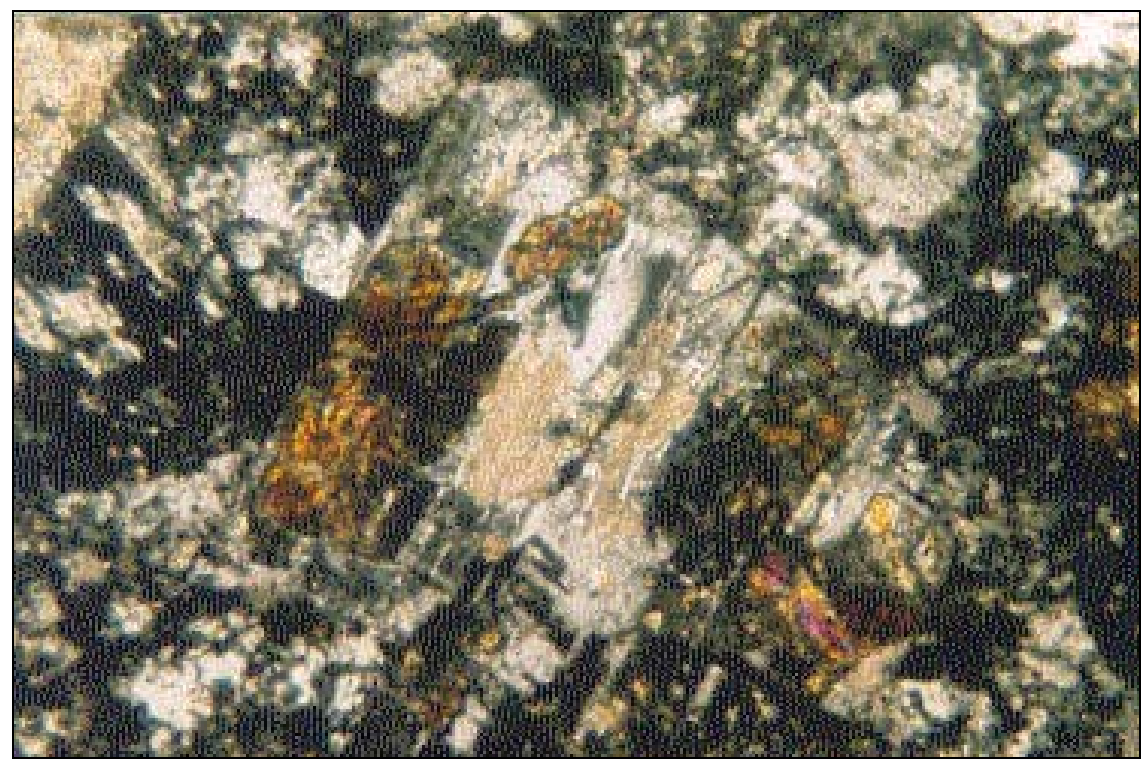

Fig. 1. The propylitic assemblage: epitote, chlorite, calcite of the quartz-monzodiorite.

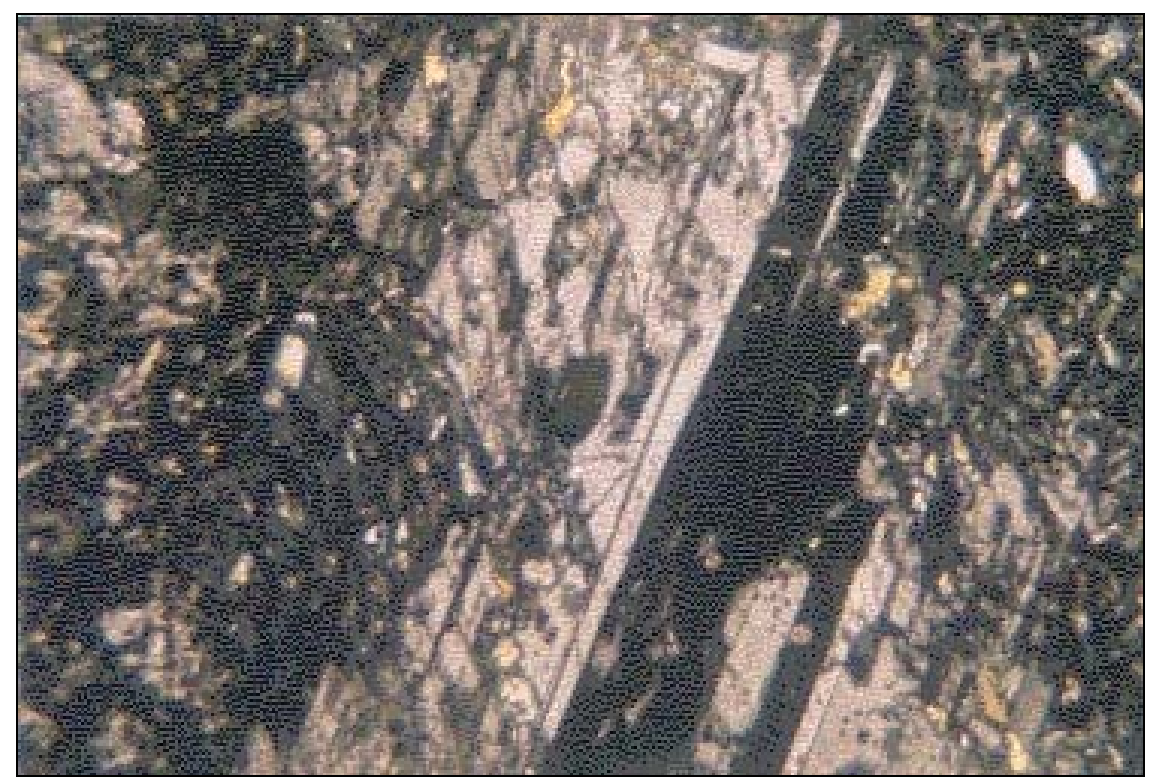

Fig. 2. The propylitic assemblage (albite-epidote) of the quartz-monzodiorite. 
THE MINERALOGICAL CHARACTERISTICS AND THE ZONING OF THE HYDROTHERMAL TYPES...

\section{PLATE II}

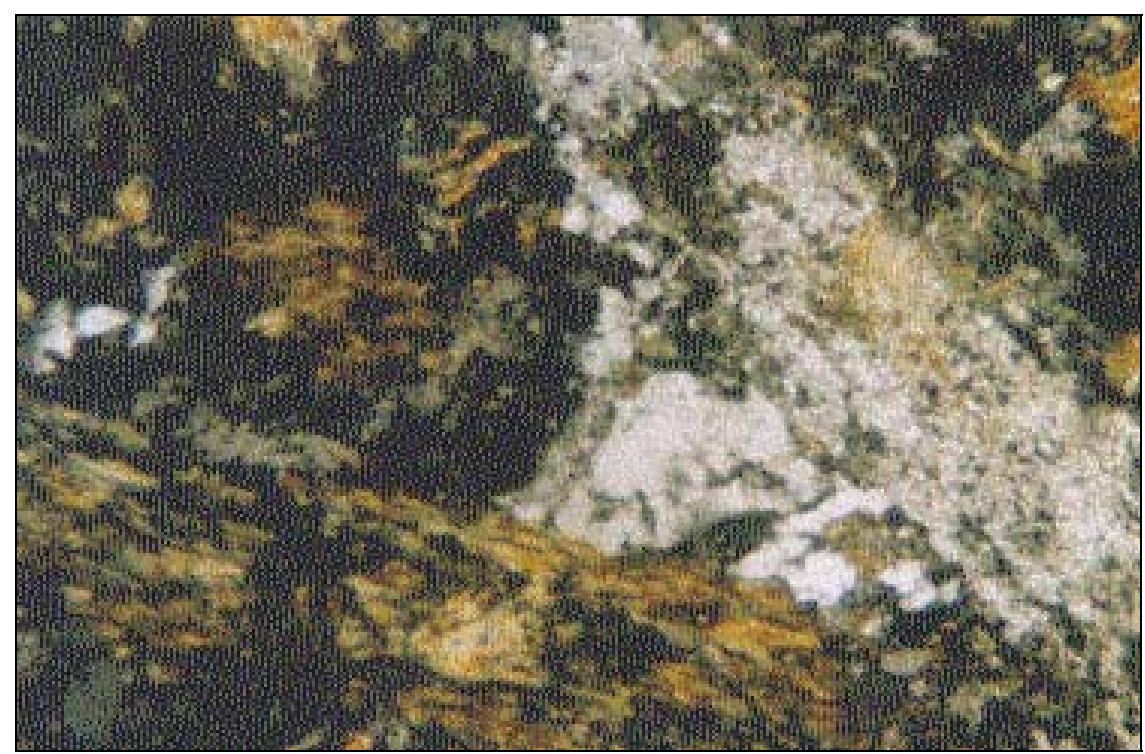

Fig. 1. The propylitic assemblage (inner propylitic of the quartz-monzodiorite).

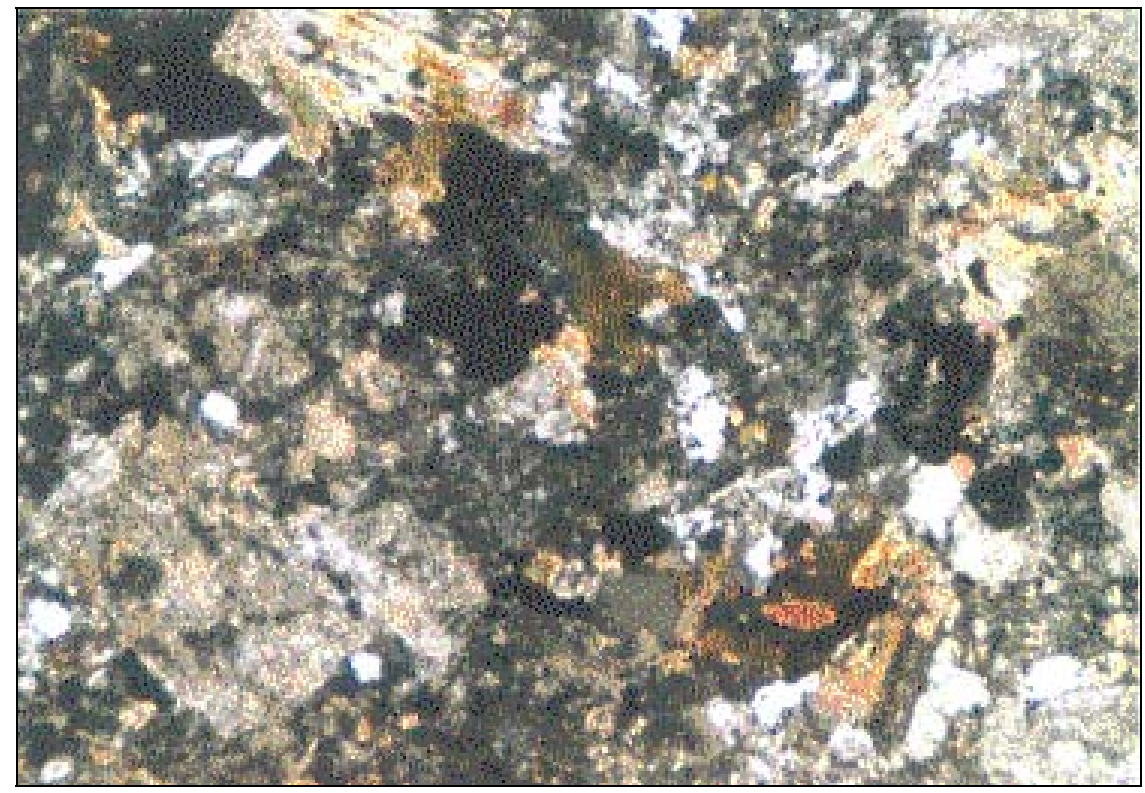

Fig. 2. Potassic assemblage (K-feldspar, biotite, sericite in quartz-monzodiorite). 
PLATE III

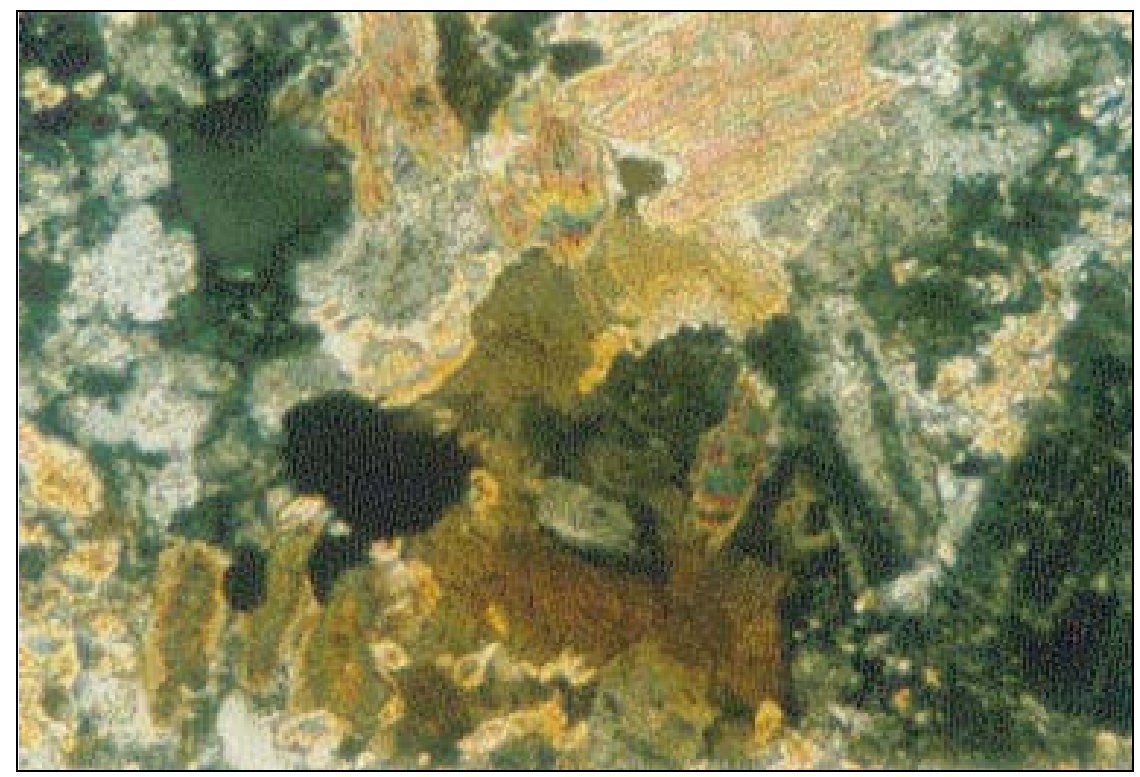

Fig. 1. Lamellar aggregates of hydrothermal biotite in potassic alteration.

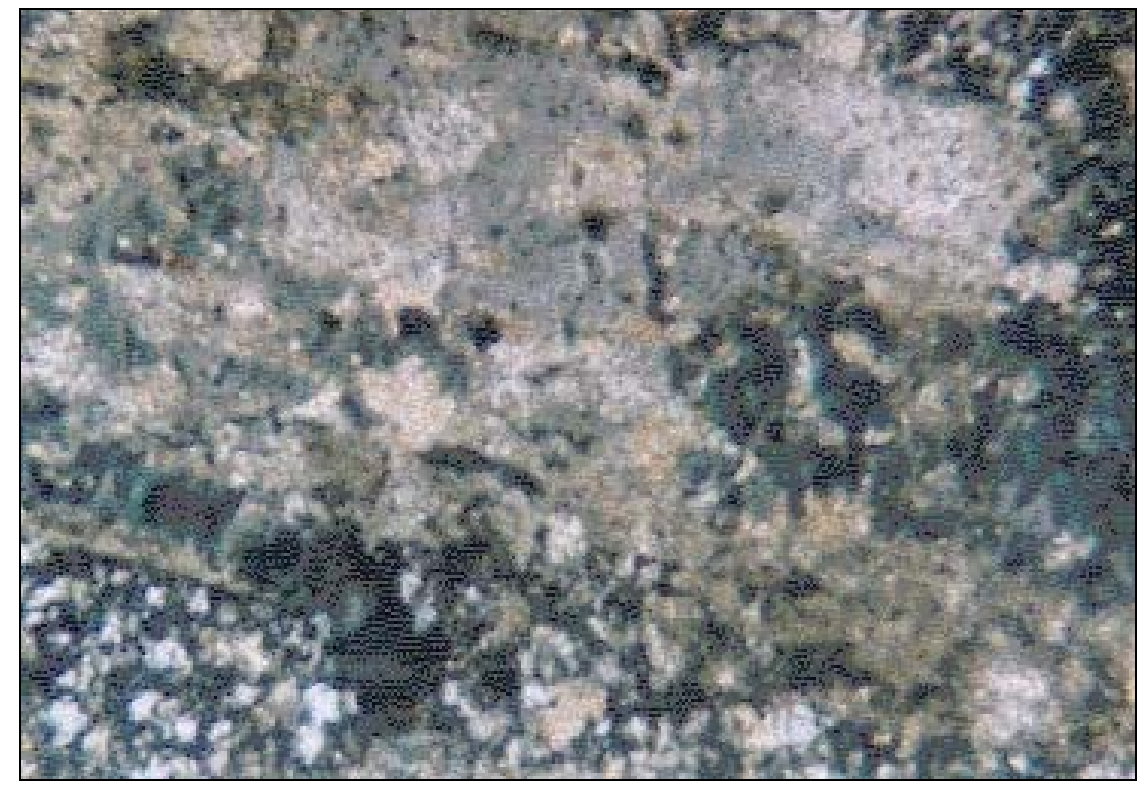

Fig. 2. Adularia alteration in pyroxene andesites. 
THE MINERALOGICAL CHARACTERISTICS AND THE ZONING OF THE HYDROTHERMAL TYPES...

\section{PLATE IV}

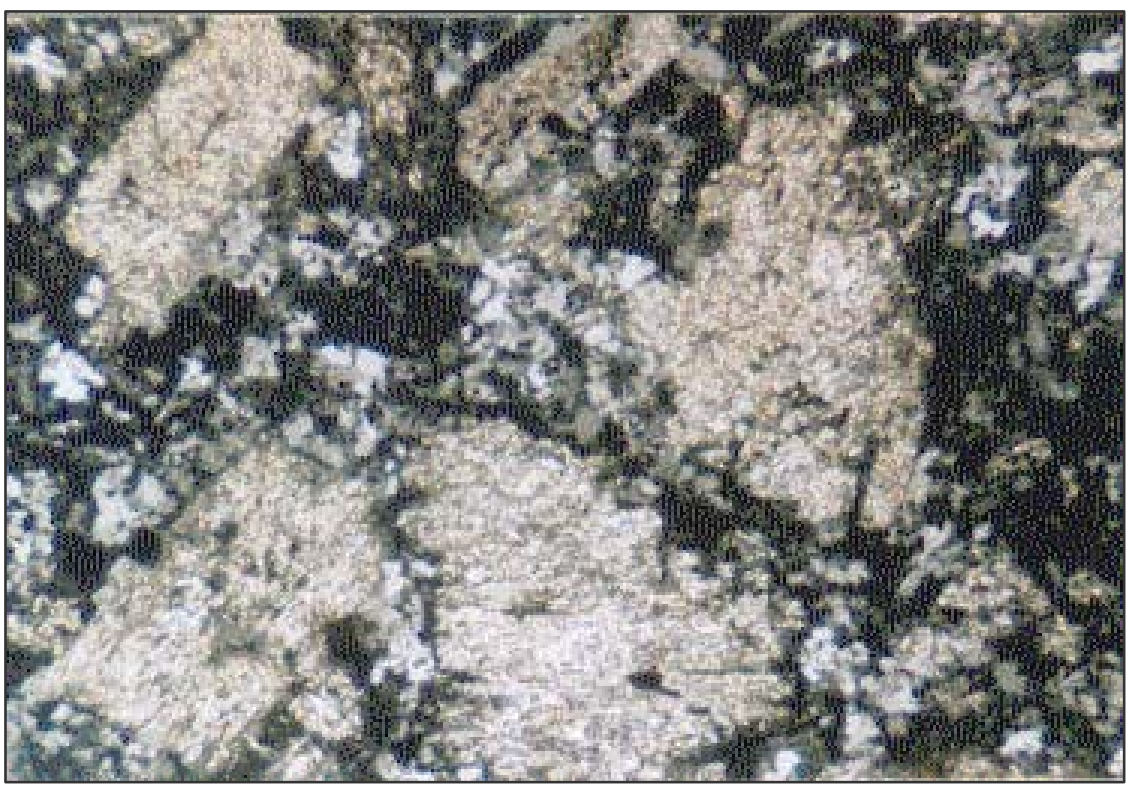

Fig. 1. Phyllic alteration in the phyroxene andesites.

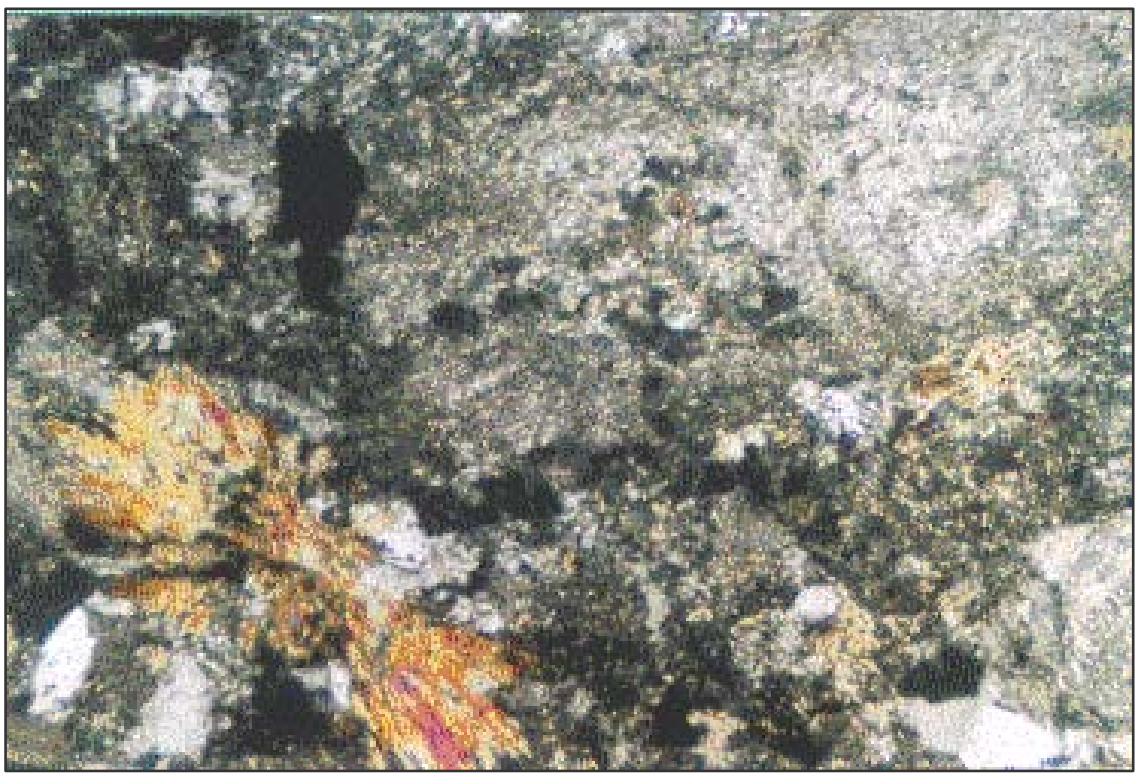

Fig. 2. Tourmaline associated whit the phyllic assemblage. 